\title{
MANYE Fordítástudományi Kutatások 1.
}

\author{
(MANYE Fordítástudományi Szakosztálya, online konferencia, \\ 2021. május 28.) \\ Németh Anikó \\ E-mail:nemeth.aniko@gtk.bme.hu
}

Egy régi-új hagyomány, a fordítástudományi PhD-kutatások bemutatásának is helyt adó konferenciasorozat újjászületésénél lehettünk jelen 2021. május 28-án, amelyet a Magyar Alkalmazott Nyelvészek és Nyelvtanárok Egyesületének (MANYE) Fordítástudományi Szakosztálya élesztett fel és indított útjára Fordítástudományi Kutatások 1. címmel, a ma már egyáltalán nem rendhagyónak nevezett virtuális térben. A konferencia szervezői egy teljes napot kitöltő, gazdag programot kínáltak számunkra, ahol a párhuzamos szekciókról lemondó program-összeállításnak köszönhetőn a résztvevőknek azonban egyetlen elöadásról sem kellett lemondaniuk. A nyelvi közvetítéshez kapcsolódó tudományterületeken átívelö, fordítás-, tolmácsolás- és terminológiakutatási témákról és empirikus kutatási eredményekröl számoltak be az előadók.

Az egész napos konferencia két nagy részből állt, összesen 17 előadót hallhattunk, a délelőtti első szekcióban 5 előadás, a délutáni két, egymást követő szekcióban pedig további 8 előadás hangzott el. Az online megrendezett konferenciának köszönhetően nemcsak Magyarországról, hanem külföldön élő vagy dolgozó, fordítástudományi kutatások iránt érdeklődők is szép számmal tudtak bekapcsolódni a tudományos diskurzusba. Ellenben a virtuális konferenciák egyik legnagyobb hátránya, hogy - a személyes találkozást és az informális kapcsolattartást nélkülözve - a szekciók közötti kávé- és ebédszüneteket ki-ki magányosan az otthonában vagy a kollégáival az irodájában töltötte.

Elsőként Prószéky Gábor, a MANYE elnöke üdvözölte a különböző helyszíneken helyett foglaló, de a Zoom közös képernyőjén egybegyült résztvevőket. Nyitóbeszédében kiemelte, hogy nyilván mindannyian áhítjuk már a személyes találkozást lehetővé tévő konferenciákat, de bízik abban, hogy a COVID-19 világjárvány miatt ma még kényszerüségből használt online platformokból a jövőbeli konferenciák előnyt kovácsolnak majd. Véleménye szerint az információs technika

Hivatkozás: Németh A. 2021. MANYE Fordítástudományi Kutatások 1. (Zoom, MANYE Fordítástudományi Szakosztálya, 2021. május 28.) Forditástudomány 23. évf. 2. szám. 117-122. DOI: https://doi.org/10.35924/fordtud.23.2.8 
vívmányairól a jövőbeli konferenciák szervezésénél sem szabad lemondani, és a személyes jelenlét mellett továbbra is lehetőséget kell majd biztosítani a konferenciákon történő online részvételre is.

Az első szekcióülés elnökeként Klaudy Kinga, a MANYE alelnöke köszöntötte a résztvevőket, és abbéli reményének adott hangot, hogy a régi hagyomány felélesztésével olyan új konferenciasorozatot indíthatnak útjára, ahol betekintést kaphatunk a legaktuálisabb fordítás-, tolmácsolás- és terminológiatudományi kutatásokba, $\mathrm{PhD}$ hallgatók mutathatják be kutatási témájukat, továbbá lehetőség nyílik a doktoranduszhallgatók és témavezetőjük közös fellépésére is. Ez utóbbira is jó például szolgál az első előadópáros, Robin Edina (Eötvös Loránd Tudományegyetem, Nyelvi Közvetítés Intézetének oktatója) és Olgyay-Fekete Judit, leendő doktoranduszhallgatójának az első közös fellépése, akik a nyelvi közvetítők szakmai és tudományos hátterét vizsgálták meg. A kutatásukat az Európai Fordítástudományi Társaság (EST) 2014-ben, 305 fordításkutató megkérdezésével végzett, online felmérése inspirálta. E kutatás eredménye rámutatott arra, hogy a megkérdezettek jelentős gyakorlati tapasztalattal rendelkeznek a nyelvi közvetítés terén. A magyarországi felmérésben a nyelvi közvetítéssel foglalkozó szakemberek szakmai hátterével, végzettségével, valamint a fordítástudományi kutatások hasznosságával kapcsolatban gyüjtöttek adatokat. A 178 beérkezett válaszból az derült ki, hogy a gyakorló szakemberek fontosnak tartják fordítástudomány és a nyelvi közvetítői szakma kapcsolatát, mivel a fordításkutatási eredmények hozzájárulhatnak a tudatosabb és hatékonyabb munkavégzéshez.

A délelőtti második előadást egy jól összeszokott kutatópáros, Balogh Dorka (Pázmány Péter Katolikus Egyetem, Jog és Államtudományi Kar oktatója) és Lesznyák Márta (Szegedi Tudományegyetem, Bölcsészettudományi Kar oktatója) tartotta. Jelenlegi kutatásukban a jogi szakfordításon, 4-5 fös csoportokban, projektmunkában dolgozó, bölcsész végzettséggel rendelkező fordítóhallgatók és a jogász képzettségű hallgatók közötti szakmai segítségkérést és segítségnyújtást elemezték. A vizsgálatban arra kerestek választ, hogy a bölcsészhallgatók menynyire tudják kihasználni a jogászok által felkínált szakmai konzultációban rejlő lehetőségeket fordításaik elkészítése során. A 2018 és 2020 között zajló kutatásban 23 bölcsész kiscsoport vett részt, akik e-mailben konzultálhattak jogász végzettségü hallgatókkal. A kutatók a konzultációk anyagát elemezve azt állapították meg, hogy a fordítóképzésben részt vevő, nem bölcsész MA hallgatók nagy százalékban nem tudják kihasználni a szakértői konzultáció kínálta lehetőségeket, kérdésfeltevési stratégiáik nem hatékonyak. A jogászok válaszainak elemzéséből kiderült, hogy a szakemberek sem mindig adnak pontos válaszokat szakmai kérdésekre. A jogi végzettség nagy előnyt jelent a jogászoknak az anyanyelvre fordításkor, de önmagában nem elég a sikeres jogi fordításhoz.

A hozzászólásokat és az első kávészünetet követően tolmácsolástudományi előadások következtek. Ebben a részben az első előadást ismét egy szerzőpáros, Seresi Márta, témavezető (ELTE, Nyelvi Közvetítés Intézete) és Láncos Petra, doktoranduszhallgatója (PPKE, Jog- és Államtudományi Kar) tartotta $A$ kognitív 
terhelés változása az online szinkrontolmácsolási platform használatakor címmel. Az elöadásuk nagyon is aktuális témát boncolgatott, hiszen a világjárvány kitörése alapjaiban változtatta meg a távtolmácsolás és tolmácsok munkakörülményeit. Kutatásukban azt vizsgálták, hogy miként hat ez az új helyzet a tolmácsok kognitív terhelésére az online tolmácsplatformok használatakor. A vizsgálatban 10 képzett konferenciatolmáccsal készítettek félig strukturált interjúkat. A válaszokból egyértelmüen kiderült, hogy új elvárások fogalmazódtak meg a tolmácsokkal szemben, mint például az események elötti technikai próba, a technikusi feladatok ellátása, valamint a chatben történő kommunikáció és ezen üzenetek fordítása a szinkrontolmácsolás közben. A megfelelő színvonalú teljesítmény biztosítása érdekében a tolmácsok két vagy három eszközt használnak párhuzamosan, ami tovább növeli a kognitív terhelésüket.

A következő előadást jelen írás szerzője (BME, Idegen Nyelvi Központ; ELTE, Fordítástudományi Doktori Program) tartotta, amelyben egy kvalitatív módszerrel végzett, interjúkon alapuló feltáró kutatás eredményeit mutatta be. A kutatás 5 férfi és 5 női képzett tolmáccsal készült interjú válaszait vizsgálta, amelyben a sokszor zárt ajtók mögött zajló tárgyalásokon közvetítő tolmácsok szerepét, nyelvi és nem nyelvi nehézségeit és megküzdési stratégiáit tárta fel. Az elemzésből az derült ki, hogy a nyelvi nehézségeket illetően nem mutatható ki jelentős eltérés más kontextusban zajló tolmácsoláshoz képest. Ellenben a nem nyelvi szempontokat figyelembe véve arra világított rá a feltáró kutatás, hogy az üzleti tolmácsolás kontextusa, a vállalatok külső vagy belső kommunikációja, a tárgyalófelek tárgyalási stratégiái és taktikái nagy mértékben befolyásolják a tolmácsok közvetítöi szerepét, és ezek megoldására különböző megküzdési stratégiákat alkalmaztak.

Az első szekció utolsó előadója, Ungár Nóra (ELTE, Fordítástudományi Doktori Program), $\mathrm{PhD}$ hallgató a jelnyelvi tolmácsolás témájában végzett kutatását mutatta be Nyelvi stratégiák és nyelvi müveletek a jelnyelvi tolmácsolásban címmel. Az elöadásában egyrészt azt vizsgálta meg, hogy a jelnyelvi tolmácsolásról készült korábbi kutatások adatai és megállapításai alapján a bemutatott nyelvi tolmácsolási stratégiák (pl. hozzáadás, helyettesítés, kihagyás, szerepváltás) példái elkülöníthetőek-e a nyelvi közvetítés során alkalmazott átváltási müveletektől, vagy bizonyos esetekben azonos jelenségnek tekinthetőek. Az előadás legizgalmasabb része egy nyilvánosan elérhetö, magyar nyelvröl magyar jelnyelvre történt tolmácsolás elemzését mutatta be. A próbakutatás célja egyrészt a jelnyelvi tolmácsolásokról készült felvételek elemzéséhez szükséges feldolgozási módszerek tesztelése volt, másrészt a COVID időszak alatti jelnyelvi tolmácsolásokból összeállított, jelentős méretü korpuszon végzett vizsgálatok eredményeiről számolt be.

Az ebédszünetet követő délutáni rész első szekciójában Robin Edina köszöntötte ismét a virtuálisan csatlakozó konferencia-résztvevőket, és mutatta be az előadókat és témáikat. Ebben a szekcióban a gépi és a humán fordítással, a hiteles fordítások helyzetével, valamint a fordítói szabadsággal kapcsolatban hangzottak el előadások. Elsőként Szlávik Szilárd (ELTE, Fordítástudományi Doktori Program), PhD hallgató adott elö a gépi fordítások utószerkesztésével kapcsolatban 
végzett feltáró kutatásáról. Előadásában kitért az elemzés alapjául szolgáló Hoeyféle ismétlésmodellre (1991), részletesen bemutatta a lexikai relációk, a centrális mondattal létrejövő kötelékek és a szöveg makropropozíciója közötti összefüggéseket. Kutatásának célja a lexikai utószerkesztési müveletek feltérképezése volt, továbbá annak vizsgálata, hogy ezek a müveletek hogyan hatnak a gépi fordítás során bekövetkező koherenciaeltolódásra. A kutatás eredménye alapján azt a következtetést vonta le, hogy a gépi fordítással a kötelékek száma alig változott, míg az utószerkesztéssel jelentősen felerősödött, a centrális mondatok száma a gépi fordításban változott, az utószerkesztést követően azonban nem volt jelentős változás.

A következő előadás a humán fordításokban és a gépi fordítás utószerkesztésében előforduló hibatípusokról szólt. A Szegedi Tudományegyetem Fordítói Kompetencia Kutatócsoportja, Lesznyák Márta, Bakti Mária és Sermann Eszter átfogó vizsgálatokat folytat azzal kapcsolatban, hogy a PACTE-modell elemei milyen szerepet játszanak a humán fordításban és a gépi fordítások utószerkesztésében. A hibatípusok körülhatárolásának céljából egy kismintás kutatást végeztek 10 fordító és tolmács mesterszakos hallgatóval. A hallgatók azonos angol forrásnyelvi jogi szöveggel dolgoztak, 5 hallgató lefordította a szöveget, 5 hallgató pedig utószerkesztette a forrásnyelvi szöveg gépi fordítását. A szövegeket 3 független értékelő javította az MQM (Multidimensional Quality Metrics 2015) hibakategória-rendszer alapján megállapított szempontok szerint (pontosság, gördülékenység, stílus, lexika/terminológia). A pilot kutatás eredményei alapján kimutatták, hogy a leggyakoribb hiba a humán fordítók és az utószerkesztők körében a megfelelő információközvetítésben, elsősorban a pontosságban és a terminológiában mutatkozott. Továbbá azt is megállapították, hogy nem találhatók olyan tipikus jegyek, amelyek alapján megállapítható, hogy az adott célnyelvi szöveg humán fordítással vagy utószerkesztéssel készült-e.

Ezután egy kitekintés következett, a romániai fordítóképzés kihívásairól hallhattunk. Kovács Gabriellától (Sapientia Erdélyi Magyar Tudományegyetem, Marosvásárhelyi Kar, Alkalmazott Nyelvészeti Tanszék) megtudtuk, hogy Romániában egyre nagyobb igény mutatkozik a müszaki fordítók iránt, ugyanakkor a fordító- és tolmácshallgatók kevésbé lelkesednek a müszaki szövegek fordításáért. Aki azonban kész belevetni magát ebbe a területbe, nagyobb eséllyel kaphat majd munkát. Romániában az egyetemi alapképzésben nincs lehetőség szakfordítókat képezni, de a szakfordítással kapcsolatos tárgyak a fordítói program részét képezik. Ugyanakkor arra a kulturális különbségre is fény derült, hogy a romániai jogszabályok szerint az egyetemi diploma megszerzését követően a hallgatók nem válnak automatikusan engedéllyel rendelkező fordítókká, ehhez külön állami vizsgát kell még tenniük.

A kávészünet előtt egy nagyon érdekes elöadást hallhattunk a fordítói szabadság és az ekvivalencia közötti kapcsolatról. Szentirmay Piroska (ELTE, Fordítástudományi Doktori Program), $\mathrm{PhD}$ hallgató egy politikai beszédként értelmezhető vers angol nyelvü forrásnyelvi változatát, illetve két magyar és két olasz fordítását 
veti össze kvalitatív szövegtani módszerek alkalmazásával. Kutatása annyiban újszerü, hogy az eddig csak sajtószövegek elemzésére alkalmazott Károly (2014) féle fordítási szövegelemző modellt a saját kutatásában szépirodalmi és funkcióközpontú szövegen alkalmazza. Az elemzésében rávilágít arra, hogy a vers múfaja ugyan nagyobb formai és tartalmi szabadságot biztosít a fordító számára, a forrásnyelvi és célnyelvi kultúra eltérése miatt azonban jelentős különbségeket kell leküzdenie. Az ekvivalencia és a fordítói szabadság különös interakcióban befolyásolja a fordítói stratégiákat.

A délutáni második részben újabb négy elöadás következett, a szekcióelnöki szerepet Seidl-Péch Olívia (BME, Idegen Nyelvi Központ) töltötte be. Elsőként Suba Réka (Sapientia Erdélyi Magyar Tudományegyetem, Marosvásárhelyi Kar, Alkalmazott Nyelvészeti Tanszék) egy sajtószöveg-elemzéssel kapcsolatos kutatásról számolt be, amelyben a romániai magyar internetes sajtó, illetve a Román Országos Hírügynökség híreinek forrásnyelvi és magyar célnyelvi fordítását vetette össze funkcionális stilisztikai és szövegpragmatikai szempontból. A forrásnyelvi és célnyelvi szövegrészletek jellemző stílusjegyeinek számbavételét követően arra a kérdésre kereste a választ, hogy az eredeti szövegrészlet domináns stílusjegyei milyen módosulásokat szenvednek a célnyelvi szövegváltozatban. A kutatás eredménye rávilágított arra, hogy a stílusekvivalenciára való törekvés jelen van, de funkcionális módosulások következnek be, hogy az üzenet átültethető legyen a célnyelvbe.

A következő előadó szintén az Erdélyi Magyar Tudományegyetemről érkezett, Sárosi-Márdirosz Krisztinától (Sapientia Erdélyi Magyar Tudományegyetem, Marosvásárhelyi Kar, Alkalmazott Nyelvészeti Tanszék) A hiteles forditás (tolmácsolás) helyzetének alakulása a világjárvány idején címü előadásában kaphattunk közelebbi képet a romániai hiteles fordítások ügymenetéröl, és a 2020 tavaszán, a világjárvány miatt először elrendelt vesztegzár miatt kialakult korlátozásokról. A kutatásában azt vizsgálta, hogy a hivatalos fordítók hogyan tudták ellátni feladataikat, milyen online és offline megoldások születtek annak érdekében, hogy a megrendelők részéről érkezett megbízások továbbra is teljesíthetők legyenek a korlátozások megsértése nélkül. A kutatás feltárta, hogy a nem megfelelő jogi szabályozás miatt a fordítók és a tolmácsok munkavégzése a vesztegzár idején nehézkesebbé vált, esetenként ellehetetlenült, szemben a bírósági és egyéb hivatalos eljárásokban közremüködő ügyvédekkel és közjegyzőkkel. Mindez főként anyagi veszteséget jelentett a hivatalos fordítóknak és tolmácsoknak. Ugyanakkor pozitív következményként elmondható, hogy a külső kényszer miatt a romániai hivatalok is tettek egy lépést az e-kormányzás és a digitális ügyintézés felé.

Skriba Orsolya, fordítástudományi PhD hallgató (ELTE, Fordítástudományi Doktori Program) egy nagyon izgalmas, mind ez idáig még kevésbé feltárt területre merészkedett. Kutatása hazai viszonylatban minden bizonnyal úttörö szerepet fog betölteni: a professzionális nyelvhasználók agyi szótérképének EEG (elektroenkefalográf) eszközzel történő feltárásán dolgozik. A járványhelyzet miatt gyakorlati kutatását még nem tudta elkezdeni, ennélfogva előadása inkább elméleti jellegü volt. Ugyanakkor világosan és érthetően tárta elénk a kutatás előzményeit, 
a korábbi eredményeket és a használni kívánt eszköz müködését. A kutatása anynyira érdekes és újszerü, hogy a résztvevőktől gratulációt is kapott a kiválasztott témához. Remélhetőleg, hamarosan az eredményeket is megismerhetjük majd, és arra is választ kapunk, hogy egybeesik-e az anyanyelvi és az első idegen nyelvi szótérkép a tudatos, professzionális nyelvhasználók esetében.

A nap utolsó előadójának általában nincsen könnyü dolga, de Szilágyi-Kósa Anikó (Károli Gáspár Református Egyetem, Német és Holland Nyelvü Kultúrák Intézete) könnyedén megbirkózott ezzel a feladattal. Előadása a tulajdonnevek magyar-német nyelvpárban történő fordításáról szólt, amelyben egy attitüdvizsgálattal kapcsolatban végzett kérdöíves felmérés eredményeit mutatta be. A kutatásában összesen 57 beérkezett választ elemzett a tulajdonnevek fordítási szokásai kapcsán. A válaszadók 80 százaléka nyilatkozott úgy, hogy a magyar személynevek sorrendjét a fordítás során felcseréli az indoeurópai nyelvek esetén. A magyar földrajzi nevek fordítása kapcsán már nem volt ilyen magas az egybehangzó vélemények aránya. Az azonban egyértelmüen kimutatható volt, hogy ebben az esetben a fordítók a fordítás célját és a megrendelő elvárását tartják szem előtt.

Ezzel elérkeztünk az előadás-sorozat végéhez, de a résztvevők továbbra is aktívak voltak, kérdéseket tettek fel, és hozzászóltak az elhangzottakhoz. Azt gondolhatnánk, hogy a késő délutáni órákban az ebédet és a kávészünetet követően már lankad a figyelem és az érdeklődés, mindenki telítődik az új információkkal és impulzusokkal, de a konferencia résztvevői mindvégig kitartottak, és nagy érdeklődéssel követték az előadásokat. Átlagosan 55 és 75 fő között mozgott egész nap a virtuálisan csatlakozott hallgatóság létszáma. Ami a konferenciaszervezést és a lebonyolítást illeti, minden az előzetesen meghirdetett programkiírás szerint alakult, két előadó cserélt talán helyet a délutáni szekciókban. A technikai háttér megfelelően müködött, az elöadók hangját jól hallottuk, és a megosztott diákat talán még jobban is láttuk, mint egy élő konferencián. A virtuális konferencia résztvevői pedig már rutinosan, megfelelően tudták kezelni a saját mikrofonjukat és kamerájukat. Az előadók többnyire jól gazdálkodtak a rendelkezésre álló beszédidejükkel, így egy-egy kérdésre közvetlenül az előadás után is maradt idő. A programszervezők azonban helyesen tették, hogy az egyes szekciókon belül külön idősávot biztosítottak a kérdéseknek és a hozzászólásoknak.

Összességében nagyon gazdag és tartalmas programot kaptak a résztvevők, az előadók pedig újszerủ és színvonalas prezentációkkal készültek. A régi-új konferenciasorozat ezzel sikeresen elstartolt. Bízom benne, hogy a lendület másokat is magával ragadott, és jövőre - akár virtuálisan, akár személyesen - újabb témákat és új előadókat is megismerhetünk!

\section{Irodalom}

Károly K. 2014. Szövegkoherencia a forditásban. Budapest: ELTE Eötvös Kiadó. Hoey, M. 1991. Patterns of lexis in text. Oxford: Oxford University Press. 